\title{
The US Military's Department Store - The Military Exchanges: Should They Be Replaced By Commercial Retailers?
}

\author{
Michael P. Hughes, Francis Marion University, USA
}

\begin{abstract}
The mission of the military exchange program is to (1) provide quality merchandise to military members and their families worldwide at competitive prices, and (2) generate income to support military morale, welfare, and recreation (MWR) programs. In overseas locations the military exchanges provide military members and their families with familiar competitively-priced, topquality American products and services, priced in US dollars. The military exchanges are agencies of the US Department of Defense (DOD). The exchanges are tax free stores. This tax advantage, in concert with the exchanges' competitive pricing, helps make the products and services offered affordable for military members on their all-too-often meager salaries. Profits from the military exchanges are channeled to MWR programs benefiting military personnel and their families worldwide. However, could and should military exchange functions be contracted to commercial businesses that are actually in the business of retail? The purpose of DOD is national defense, not retail sales and the related logistics. While the original need for establishing a military-operated exchange program was valid many years ago when the commercial sector was not capable supporting worldwide military operations and operating locations, is that still the case? Could a negotiated contract with a major commercial retailer provide service members and their families with better products, at better prices, and with better service, all at reduced cost to the US government, hence reduced cost the US taxpayers?
\end{abstract}

Keywords: Department of Defense; Military Retail; Military Exchange; Military Morale, Welfare, and Recreation

Suggested Course Usage: This case study is targeted primarily towards MBA courses, particularly capstone, finance, and management courses. It is also useful for upper-level undergraduate courses, again particularly capstone, finance, and management courses.

\section{MISSION}

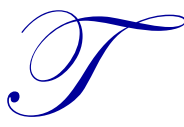

he mission of the military exchange program is to (1) Provide quality merchandise to military members and their families worldwide at competitive prices, and (2) Generate income to support military morale, welfare, and recreation (MWR) programs.

\section{BACKGROUND}

In 1895 to support soldiers stationed in the far, remote west of what was then US territories, the Army created a military exchange - a military store - to provide these soldiers with many of the goods and services they had enjoyed back home in the more eastern regions of the country. This was good for troop morale, hence the effectiveness of the army units stationed in these remote regions. The Navy's exchange service got its start in 1896 when the first canteen (ship's store) was established on the battleship USS Indiana. Over time the concept spread to other ships of the Navy. In all cases of military exchanges, the underlying idea was to provide soldiers, sailors, Marines, and, later, airmen with a bit of "home" by providing them many of the products and services that they were familiar with while they were stationed in remote and foreign locations or at sea. 
Since those earlier times military members have enjoyed having their own department stores located on military bases worldwide. These department stores - the military exchanges - are agencies of the US Department of Defense (DOD). The military exchanges are tax free stores. This tax advantage, in concert with the exchanges' competitive pricing, helps make the products and services offered affordable for military members on their all-toooften meager salaries. Profits from the military exchanges are channeled to morale, welfare, and recreational (MWR) programs benefiting military personnel and their families worldwide.

In overseas locations the military exchanges provide military members and their families with familiar American products and services, priced in US dollars. Along with American products and services, these foreignbased exchanges often also sell indigenously-produced products at very competitive prices compared to stores in the local economies. Overseas-based members of the US military and their families rely on these stores for many, if not most of their personal needs. The exchanges further shield these military customers from unduly high local prices, which are often the result of fluctuations in exchange rates between the US dollars that the military members are paid in and the local currency that they must use to purchase goods and services in the local economies.

Back home in the US the military exchanges provide military members and their families with competitively-priced, top-quality products. Further, the exchanges guarantee that their prices are lower than any local competitors and will, at a minimum, match the prices of those competitors. Since the exchanges conduct business on military bases, which are legally federal property not under the jurisdiction of the respective states where the bases are located, exchange customers are not charged state or local sales taxes. This tax advantage furthers the cost savings afforded military members and their immediate families. This especially helps stretch the limited budgets of younger and lower ranking members of the military, particularly the young enlisted members.

The military exchanges offer a credit card program, the Military STAR Card. The Military Star Card is much like a store credit card that is only good at that store (e.g., a Sears' credit card good only at Sears). The Military Star Card is managed by the Exchange Credit Program (ECP), a function of DOD's exchange program. The Military Star Card allows military personnel, active duty or retired, and their immediate family access to credit at military exchanges worldwide. In more recent times ECP has enhanced the credit program by entering into an arrangement with MasterCard to provide new versions of the Military Star Card. These new cards are usable at businesses beyond just the military exchanges, such as off-base retailers (e.g., Walmart). As with the military exchange retail function, profits from the Military Star Card are channeled to MWR programs.

In addition to its own retail functions, the military exchanges also host commercial fast-food providers under contract (contracted concessions). Such commercial providers include McDonald's, Burger King, Taco Bell, Subway, and many others. ${ }^{1}$ The tax-free advantage is applied here as well for the same reasons previously stated. Further, when using a Military STAR Card to pay for the food, a further 10-percent is deducted from the bill. In many cases the exchanges also operate their own cafeterias.

On most military installations the exchanges provide gas stations where members of the armed forces and their families can buy gasoline, automotive products such as motor oil, and other commonly available automotive products at highly competitive prices. Quite often automotive services are also offered such as tire replacement, alignments, tune-ups, and similar automotive maintenance services. Again, these exchange retail functions are free of state and local taxes; hence, they can be priced below competitors' prices in the local economies. Frequently in overseas locations this retail function offers the only reasonably-priced source of gasoline and other automotive products to military members and their families.

Military exchanges sell alcoholic beverages, again, tax free. Since military installations are considered federal property in the US or US sovereign property in overseas locations, local laws and regulations concerning the purchase of these beverages usually do not apply (e.g., state or local prohibitions on Sunday sales of alcoholic beverages generally do not apply on military installations). One exception to this is that at most military installations within the US, the exchanges limit the minimum age for the purchase of alcoholic beverages to that specified by the host state. Further, in a few cases where a specific Status of Forces Agreement with a host foreign

${ }^{1}$ Sometimes these are regional or even local providers. 
nation places the installation under the sovereign laws of that host nation, the local laws apply. That said, in most cases of overseas military installations such sales are exempt from local laws and regulations. Nowhere is this more evident than in many Islamic nations where the sale of alcoholic beverages is strictly prohibited at any time; but the sale of these products is allowed on US military installations within those nations. These products, however, must remain on the installation.

The military exchanges also offer an Internet-based retail capability so that military members and their families can shop online and take delivery of the products through the mail or other shipping method.

The military exchanges are divided among and operated by the individual military service branches, although all members of the armed forces can use any service's exchange with proper military or dependent identification. ${ }^{2}$ The Army and Air Force jointly operate the Army and Air Force Exchange Service (AAFES), while the Navy operates the Navy Exchange Service Command (NEXCOM, usually just referred to as NEX), the Marine Corps operates the Marine Corps Exchange (MCX), and the Coast Guard operates the Coast Guard Exchange (CGE). ${ }^{3}$ AAFES, by far the largest of the exchange programs, has over 3,700 exchanges on Army and Air Force installations around the world. NEX has operating locations on naval facilities and aboard most naval vessels. ${ }^{4}$ MCX operates around 170 facilities worldwide.

As previously mentioned, the military exchanges do more than just provide products and services at competitive prices to members of the armed forces and their families. Significant funds from exchange-generated profits are reinvested back into military community activities, such as MWR programs. These quality-of-life programs include, but are not limited to, rest and recuperation activities and facilities for military members and their families. Given the nature of the military occupation, such facilities are a necessity. Further, abundant youth activities exist that provide military children with various constructive pursuits of their time. This is especially important in overseas locations where all-too-often cultural and language differences can make the children of military members feel isolated, with the resultant boredom and possibly less-than-healthy activities.

Military-exchange privileges are extended to military retirees and their immediate families as well. The military exchanges offer special retiree-focused councils and considerations, such as the AAFES Director's Exchange Retiree Advisory Council (ERAC). The ERAC is made up of military retirees who represent retiree issues to the exchanges and advocate for those retirees.

An additional benefit of the military exchanges is that they provide employment opportunities for the families of military personnel. For example, in 2011 around 30-percent of AAFES employees were reported to be military family members, while 13-percent were military veterans. The extra income earned by a spouse or child of the military member is quite welcomed to help bolster all-too-often rather meager military pay, particularly in the lower ranks. This also helps maintain a sense of home, usefulness, and worth to the families of military members in overseas locations. ${ }^{5}$

\section{MILITARY EXCHANGE FINANCIALS}

Around 98-percent of AAFES operational funding is derived from its sale of goods and services. Appropriated DOD funds account for the remaining 2-percent of AAFES' operational budget. Around 67-percent of

\footnotetext{
${ }^{2}$ Dependents are usually immediate family members.

${ }^{3}$ Although the Coast Guard (CG) in times of peace exists under the Department of Homeland Security (DHS) and not the Department of Defense (DOD), it is nonetheless considered one of five branches of the armed forces of the United States, along with the Army, Air Force, Navy, and Marine Corp as described by Title 10 of the United States Code (USC). During war the CG becomes an element of the Navy and then falls under DOD command. The reason that the peacetime CG is under DHS is that the CG conducts and is involved in various law enforcement activities as described and authorized by Title 14 USC. Title 18 USC prohibits the military, except for the CG, from conducting law enforcement activities. This is known as the Posse Comitatus Act. The CGE at all times operates as a military exchange with exactly the same functions and eligibility requirements of AAFES, NEX, and MCX.

${ }^{4}$ The number of naval exchanges fluctuates as the number of ships in the Navy changes.

${ }^{5}$ Families are not able to accompany the military member in all overseas locations. In combat arenas and several other remote locations having families accompany the military member is not possible or desirable for many reasons. Obviously, families cannot accompany their military member aboard naval ships.
} 
AAFES earnings are directed towards MWR activities and facilities. This mimics the other service branches' exchange operations.

In Figure 1 the right side of the AAFES balance sheet is described as "Liabilities and Net Assets." "Net Assets" is substituted for the more common "Equity" seen in most commercial business balance sheets because AAFES is a government, hence taxpayer-owned enterprise. The net assets represent the assets that have been allocated to AAFES. They are treated in much the same manner as equity would be in a commercial business. The "Statements of Earnings" are the government's equivalent of "Income Statements" for commercial business. Only the AAFES financial statements are provided here because AAFES is by far the largest of the military exchange operations and, other than size, the AAFES statements are generally representative of the other services' exchange operations.

As can be seen from Figure 1, the AAFES exchange operation is quite large with net sales of $\$ 8.7$ billion in the fiscal year ending January 28, 2012 (i.e., FY 2011). Add to this the sales from NEX, $\$ 2.8$ billion, and the smaller, yet significant MCX and CGE, and the total 2011 sales for the military exchange system was $\$ 12.8$ billion, excepting contracted concessions. This annual sales figure, while not as large as the Walmart's (the world's largest retailer) 2011 sales revenue of $\$ 419$ billion (Walmart, 2012), nonetheless places the military exchange system among the world largest retailers. For example, Bed, Bath and Beyond, Inc.'s 2011 sales revenue was $\$ 8.6$ billion (MarketWatch, 2015a) and J.C. Penny, Inc.'s sales revenue was \$17.76 billion (MarketWatch, 2015b). Hence, a question arises: Is being among the largest retailers in the world the job of the Department of Defense? 


\section{Army and Air Force Exchange Service (AAFES) Balance Sheets}

(Dollars in thousands, unless otherwise noted)

Assets

Current assets:

Cash and cash equivalents

Trade and other accounts receivable, less

allowance for uncollectible accounts (at January 28, 2012 - \$43,324, at January 29, $2011-\$ 42,561$ )

Merchandise inventories

Short-term investments

Supplies and other current assets

Total current assets

Buildings and improvements

Fixtures and equipment

Construction-in-progress

Accumulated depreciation

Other assets

Prepaid pension assets

Long-term investments and Supplemental Plan assets

Total assets

\section{Liabilities and Net Assets}

Current liabilities:

Accounts payable

Notes payable to banks

Accrued salaries, separation pay, and other employee benefits

Dividends payable

Other current liabilities

Total current liabilities

Notes payable to banks - long-term

Accrued pension and other benefits

Other noncurrent liabilities

Total liabilities

\section{Net assets:}

Accumulated other comprehensive loss:

Pension liability

Derivative instruments

Total accumulated other comprehensive loss

Retained earnings

Total net assets

Total liabilities and net assets
January 28, 2012

January 29, 2011
$\$ \mathbf{1 1 2 , 0 7 5} \quad \$ 100,778$

$\mathbf{3 , 6 8 0 , 3 1 6} \quad 3,531,405$

$\mathbf{1 , 4 1 2 , 0 3 6} \quad 1,520,344$

$\mathbf{1 0 , 3 0 0} 22,548$

$\mathbf{4 8 , 4 2 3} \quad 38,093$

$\mathbf{5 , 2 6 3 , 1 5 0} \quad 5,213,168$

$\mathbf{3 , 1 8 6 , 2 6 9} \quad 3,102,074$

$\mathbf{1 , 4 0 5 , 7 3 8} \quad 1,404,923$

$\mathbf{2 7 9 , 3 9 4} 179,457$

$\mathbf{4 , 8 7 1 , 4 0 1} 4,686,454$

$(\mathbf{2 , 4 9 9 , 4 2 8 )} \quad(2,372,230)$

$\mathbf{2 , 3 7 1 , 9 7 3} 2,314,224$

$\mathbf{2 , 5 9 0} 603$

- $\quad 402,563$

$\mathbf{3 5 , 0 9 3} 23,864$

$\$ \mathbf{7 , 6 7 2 , 8 0 6} \$ 7,954,422$

Figure 1. Army and Air Force Exchange Service Financial Statements for fiscal years 2010 and 2011. In the balance sheet the "right side" is titled "Liabilities and Net Assets." "Net Assets" is substituted for the more common "Equity" seen in most commercial business balance sheets because AAFES is a government, hence taxpayer-owned enterprise. The "Statements of Earnings" are the government's equivalent of "Income Statements" for commercial business. These statements are from the Army and Air Force Exchange Service Annual Report for 2011 (AAFES, 2012a). 
Army and Air Force Exchange Service Statements of Earnings

(Dollars in thousands, unless otherwise noted)

\begin{tabular}{|c|c|c|}
\hline Year Ended & January 282012 & January 292011 \\
\hline Net sales & $\$ 8,658,849$ & $\$ 8,244,004$ \\
\hline Finance revenue & 281,281 & 253,553 \\
\hline Concession income & 207,891 & 213,763 \\
\hline Other operating income & $\mathbf{3 6 , 2 7 7}$ & 36,935 \\
\hline Total revenue & $9,184,298$ & $8,748,255$ \\
\hline \multicolumn{3}{|l|}{ Cost of sales and operating expenses: } \\
\hline Cost of goods sold & $6,742,032$ & $6,308,863$ \\
\hline \multicolumn{3}{|l|}{ Selling, general, and administrative: } \\
\hline Employee compensation and benefits & $1,161,675$ & $1,151,106$ \\
\hline Depreciation and amortization & 321,848 & 316,647 \\
\hline Other & 576,370 & 532,125 \\
\hline Total selling, general, and administrative expenses & $2,059,893$ & $1,999,878$ \\
\hline Interest expense & 51,505 & 50,843 \\
\hline Bad debt expense & 60,170 & 9,608 \\
\hline Total expenses & $.8,913,600$ & $8,369,192$ \\
\hline Operating income & 270,698 & 379,063 \\
\hline Other income & 7,121 & 11,826 \\
\hline Net earnings & $\$ 277,819$ & $\$ 390,889$ \\
\hline
\end{tabular}

\section{THE CONTRACTING QUESTION}

Again, the mission of the military exchange program is to:

1. Provide quality merchandise to military members and their families worldwide at competitive prices.

2. Generate income to support military morale, welfare, and recreation (MWR) programs.

As previously discussed the military exchanges are agencies of DOD which are operated by the respective service branches, as is the ECP with its Military Star Card function. The fast-food providers - concessions-are provided by commercial businesses under contract. These contracted activities by all accounts operate effectively and efficiently, addressing the military exchange mission requirements at least satisfactorily, if not excellently. These concessions even operate on many foreign-based US military installations. The question is, can and should all of the military exchange functions be contracted activities as well? The purpose of DOD is national defense, not retail sales. While the original need for establishing a military-operated exchange program may have been valid many years ago when the commercial sector was not capable of supporting worldwide military operations and operating locations, is that still the case? Could a negotiated contract with a major commercial retailer provide service members and their families with better products, at better prices, and with better service, all at reduced cost to the US government, hence reduced cost the US taxpayers? After all commercial retailers are in the business of conducting retail operations and the associated logistics - this is what they do best because it is why they exist. A similar argument could be made for the ECP credit function that would suppose that a commercial bank may be better suited, at reduce cost, to service the military credit program. This is what banks are in business to do. On the other hand, DOD exists for the purpose of and is this nation's foremost expert in national defense.

If replacing the current military exchange system with a contracted commercial business is something sufficiently viable to be investigated, then the next question would be, should just the US-based exchanges or all the exchanges worldwide be contracted to commercial business? What about in combat arenas or aboard naval vessels? In short, would a company such as Walmart or Target, with their well-established logistics and marketing capabilities, be able to provide at least the same level of service at lower prices through such economic phenomena as economies of scale? Could a significant portion of the profits of these commercially-run operations be used to support MWR activities much in the same way that the current exchanges do? Or could the government create a separate, privately-owned and operated, but government-sponsored enterprise (GSE) to manage and operate the military exchange system? Or is the current arrangement the optimal solution? 
Critics of replacing the current military exchange system with contracted commercial businesses argue that the military exchange program has been and remains mostly self-funded, and it produces significant cash flow to fund MWR programs. They fear that if DOD was to adopt the commercial contractor route for all exchange functions that over time the unique requirements of the military would not be served as well as they currently are. Further, they fear that financial support of MWR programs would evaporate away in the interests of commercial profits and politics, at both the national and local levels. Such fears may be well founded based on real-world experience with the commercial sector and in the political arenas of government. How could these fears be addressed? Closely related to this is that fact that the exchange privileges enjoyed by the military are seen as noncash military compensation that could possibly be jeopardized by contracting the exchange functions to commercial businesses. If that non-cash compensation were to be lessened - or even perceived to be lessened - then the salaries of military personnel would have to be raised sufficiently to make up for the loss, otherwise recruitment and retention could suffer greatly. ${ }^{6}$ The increase in military salaries necessary to offset the potential reduction or loss of the exchange benefit, would represent a large cost increase to the government; hence, the US taxpayers. In short, the critics do not want to allow this military benefit to get too much outside of DOD control.

In 1997, in an effort to better understand this matter, the Congressional Budget Office (CBO) studied DOD's retail activities and produced a paper, "The Costs and Benefits of Retail Activities at Military Bases" (Congressional Budget Office, 1997). The study was part of an overall effort aimed at reducing DOD costs to free up money for replacing obsolescent and worn-out military equipment. This study was conducted in concert with the closing of suddenly redundant military installations around the world in the years following the end of the Cold War. The study evaluated the social and budgetary costs and benefits of all of DOD's retail activities. ${ }^{7}$ The conclusion of this study was that the DOD's justification for maintaining the exchanges ${ }^{8}$ was not tenable. The report stated that the military exchanges were not a cost effective way of maintaining DOD's required recruitment and retention levels. The $\mathrm{CBO}$ report voiced the opinion that DOD has maintained the exchanges primarily because the real costs of the program do not show up in DOD's financial documents; therefore, exist outside of DOD's budget line. Providing increased military salaries, however, would show up in these documents and would, as a result, fall within DOD's budget. That would make DOD directly answerable for any costs associated with these retail activities in ways that they aren't today. The CBO report concluded that "Any meaningful debate over DOD's future retail activities may have to balance the inefficiency of subsidized, government-run stores as a way to attract and retain a high-quality force against the disrupted expectations and transition costs associated with changing that system" (Congressional Budget Office, 1997).

Over 17 years have gone by since that report and its follow-on testimony to Congress in 1998. The military exchange system remains as it was before. Only the closure of military bases around the world, along with a general reduction in the size of the military has reduced military exchange operations. Military members and their families still use and value the exchanges as much as they ever did, and there is no doubt that major changes to it would be met with profound apprehension and distrust. But if something better were to be offered, something with better goods and services, at better prices, and still was able to fund the MWR programs at least to the levels they currently are funded, along with concrete guarantees that the politicians would keep their hands off the money, ${ }^{9}$ then the military community might be amenable to such changes.

\footnotetext{
${ }^{6}$ The voluntary recruitment of personnel to the ranks of the military is mostly a post-Vietnam development that is jealously guarded by DOD. If the voluntary recruitment process was suddenly unable to provide sufficient numbers of qualified personnel to fill the ranks of the military, especially during periods of war, then DOD would have to resort to the draft again. DOD seeks to avoid this possibility by offering military personal either competitive salaries or, in the absence of that, providing offsetting military benefits sufficient to induce recruitment and then support the retention of highly trained and experienced personnel. The retention of these critical personnel who are necessary to maintain an effective and viable national defense is a major concern for DOD leadership.

${ }^{7}$ The study included other military retail activities such as commissaries, which are the military equivalent of grocery stores. These other retail activities are outside of the scope of this paper, but any decision made in regards to the military exchanges would have major implications for these other activities as well.

${ }^{8}$ And other military retail activities.

${ }^{9}$ DOD has been a place where politicians have traditionally gone looking for additional funds for pet projects or to make up budget shortfalls by raiding the DOD budget. Military members are precluded from criticizing elected leaders in the manner that that employees of civilian agencies can. This is why there are many non-profit, private military-related organizations, such as the Air Force Association, which seek to provide a voice for the military members who under the duress of law cannot otherwise criticize political decisions. This is the nature of military service. Further, many active-duty personnel know all-too-well that the government has broken its promises to and contracts with members of the armed forces before, such as the Vietnam GI Bill and healthcare for military retirees.
} 


\section{DISCUSSION QUESTIONS}

1. Should the Department of Defense be in the retail business?

2. Should military personnel be afforded separate shopping facilities with the incumbent tax and often price advantages? If not, what about in operating locations outside the US? Consider the impact on recruitment and retention of highly trained and skilled military personnel, hence the nation's defense capabilities (i.e., a weapon/defense system is no better or capable than the personnel trained to operate and maintain it).

3. If this military retail service is to be retained, either domestically or in foreign operating locations, or both, but is to be operated outside of DOD, should the operation be contracted to a commercial retailer or should a government sponsored enterprise (GSE) be established exclusively for this purpose?

4. How can military personnel and their families be assured that politicians seeking funding for politicallyexpedient projects won't "raid" or "steal from the cookie jar" at the military personnel's expense?

5. What about contracting host-nation foreign providers for US military operating locations in the respective foreign nations?

6. If this military retail service is to be retained, but contracted to a commercial retailer, how often should the contract be renegotiated or open to competitive bidding again? Consider the expenses in establishing the requisite logistic channels. Or should a commercial retailer be awarded the contract indefinitely with DOD oversight, to include cost controls?

\section{AUTHOR INFORMATION}

Michael P. Hughes is an associate professor of finance at Francis Marion University in Florence, South Carolina. Dr. Hughes holds a Ph.D. in finance, an MBA, and a BSET in operations. Dr. Hughes' research interests lie in financial markets, market microstructure, financial econometrics, fixed income securities, central banking, and government finance, to include defense finance. Prior to his being an academic Dr. Hughes served for over 21 years in the US Air Force. Dr. Hughes is the son of a retired US Air Force fighter pilot and grew up in the air force. Dr. Hughes has three sons of his own, two of whom are career military officers. E-mail: mph-main@ftc-i.net

\section{REFERENCES}

AAFES (2012a). “Army and Air Force Exchange Service Annual Report, 2011.” Retrieved from http://www.alanational.org/government/researchcenter-government.aspx.

Congressional Budget Office (1997). "The Costs and Benefits of Retail Activities at Military Bases." Retrieved from https://www.cbo.gov/sites/default/files/cbofiles/ftpdocs/1xx/doc158/retail.pdf.

MarketWatch (2015a). Bed, Bath, and Beyond, Inc. Retrieved from http://www.marketwatch.com/investing/stock/bbby/financials.

--- (2015b). J.C. Penny, Inc. Retrieved from http://www.marketwatch.com/investing/stock/jcp/financials.

Walmart (2012). "Walmart 2011 Annual report." Retrieved from http://c46b2bcc0db5865f5a7691c2ff8eba65983a1c33d367b8503d02.r78.cf2.rackcdn.com/2b/16/fa19acd64b60b475e6efaa1013b3/2011annual-report-for-walmart-stores-inc_130221022810084579.pdf.

\section{SUGGESTED ADDITIONAL REFERENCES}

About Money (2014). “2014 US Retail Industry Overview - Info, Facts, Research, Data, Trivia: Definition \& Size of US Retail Industry - Types of Retailers \& Largest Chains.” Retrieved from http://retailindustry.about.com/od/statisticsresearch/p/retailindustry.htm.

AAFES (2012b). "The Army and Air Force Exchange Service 2016 Strategic Plan.” Retrieved from http://www.ala-national.org/government/researchcenter-government.aspx.

--- (2014). "Exchange History." Retrieved from http://www.aafes.com/about-exchange/history-mission/.

--- (2015). "Exchange Retiree Advisory Council.” Retrieved from http://www.aafes.com/about- exchange/militaryretiree-connection/erac.htm.

--- (1998). "Statement of Deborah Clay-Mendez Acting Deputy Assistant Director National Security Division Congressional Budget Office on Retail Activities at Military Bases before the Special Oversight Panel on 
Morale, Welfare, and Recreation Committee on National Security, U.S. House of Representatives."

Retrieved from http://www.cbo.gov/sites/default/files/ cbofiles/ftpdocs/3xx/doc355/030398.pdf.

CGE (2014). "Coast Guard Exchange." Retrieved from http://www.uscg.mil/d1/airstaCapeCod/cgx/cg_exchange.asp.

DOD (July 14, 2005). "Armed Services Exchange Regulations.” Department of Defense Instructions, Number 1330.21Retrieved from http://www.dtic.mil/whs/directives/corres/pdf/133021p.pdf.

Exchange Credit Program (2014). "Military Star Card." Retrieved from https://www.myecp.com/HtmlPages/CP_MilStartCard.

MCX (2014). "MCX." Retrieved from http://www.mymcx.com/.

Military One Source (2014). "Understanding and Using Your Military Exchange." Retrieved from http://www.militaryonesource.mil/shopping?content_id=268514.

NEXCOM (2012). "Navy Exchange Service Command 2011 Annual report.” Retrieved from https://mynavyexchange.com/command/about_us/Annual\%20Report11.pdf.

--- (2014). "NEX." Retrieved from http://www.mynavyexchange.com/.

OSD (2010). "The Exchange Corporate Sustainability Program FY10 Secretary of the Army Environmental Award Nomination for Sustainability - Team.” Office of the Secretary of Defense. Retrieved from http://denix.osd.mil/awards/upload/ Army_Exchange_Sust-Narrative.pdf.

The President's Save Award (2010). “Allow Walmart to Compete to Replace AAFES.” Retrieved from http://retailindustry.about.com/od/statisticsresearch/p/retailindustry.htm. 
NOTES 